\title{
Probiotic administration modifies the milk fatty acid profile, intestinal morphology, and intestinal fatty acid profile of goats
}

\author{
A. L. Apás, ${ }^{*} \dagger$ M. E. Arena, ${ }^{*} \dagger^{1}$ S. Colombo, ${ }^{*}$ and S. N. González ${ }^{*} \dagger$ \\ *Facultad de Bioquímica, Química y Farmacia, Universidad Nacional de Tucumán (UNT), Ayacucho 471, 4000, Tucumán, Argentina \\ †Centro Científico Tecnológico Tucumán, Consejo Nacional de Investigaciones Científicas y Tecnológicas, San Miguel de Tucumán, 4000, \\ Tucumán, Argentina
}

\section{ABSTRACT}

The effect of a mixture of potentially probiotic bacteria (MPPB; Lactobacillus reuteri DDL 19, Lactobacillus alimentarius DDL 48, Enterococcus faecium DDE 39, and Bifidobacterium bifidum strains) on the milk fatty acid (FA) profile, with emphasis on cis-9,trans-11 conjugated linoleic acid (CLA) in the middle stage of goat lactation, was determined. In addition, the effects of MPPB feeding on the FA profile in intestinal content and intestinal morphology in weaned goats were analyzed. The probiotic supplement was able to modify FA composition of milk and intestinal content. The unsaturated FA concentrations in milk ( $\mathrm{g}$ of FA/L of milk) increased from 4.49 to 7.86 for oleic (18:1), from 0.70 to 1.39 for linoleic (18:2), from 0.063 to 0.187 for linolenic (18:3) acid, and from 0.093 to 0.232 for CLA. The atherogenicity index diminished 2-fold after MPPB ingestion. In the intestinal content of the weaned goats, no significant difference in saturated FA concentration compared with the control was observed. However, oleic acid, linolenic acid, CLA, and docosahexaenoic acid concentrations increased by $81,23,344$, and $74 \%$, respectively, after probiotic consumption. The ruminal production of CLA was increased by the MPPB. However, bacterial strains of MPPB were unable to produce CLA in culture media. By histological techniques, it was observed that the treated group had intestinally more conserved morphological structures than the control group. The results obtained in this study indicate that the MPPB administration in lactating and weaned goats allows for the production of milk with improved concentrations of beneficial compounds, and also produces a protective effect in the goat intestine. The results obtained in this study reinforce the strategy of probiotics application to enhance goat health with the production of milk with higher concentrations of polyunsaturated FA.

Received December 5, 2013

Accepted August 5, 2014.

${ }^{1}$ Corresponding author: arename@fbqf.unt.edu.ar
Key words: goat, fatty acid, probiotic, milk, conjugated linoleic acid

\section{INTRODUCTION}

Ruminant meat, milk, and other dairy products are the predominant sources of CLA (Jones et al., 2005). The major CLA isomer in natural products is cis9 ,trans-11, also known as rumenic acid, which is considered to be the biologically active isomer (Serafeimidou et al., 2012).

Conjugated linoleic acid consumption could provide beneficial health properties. Conjugated linoleic acid inhibits the initiation of mouse skin carcinogenesis (Ha et al., 1987), mouse forestomach (Ha et al., 1990), and rat mammary tumorigenesis (Ip et al., 1991). In addition, CLA has been observed to inhibit the proliferation of human malignant melanoma, and colorectal, breast, and lung cancer cell lines (Parodi, 1997). On the other hand, CLA consumption contributes to fat loss and lean gain (West et al., 1998; DeLany et al., 1999; Piperova et al., 2004) as well as to reduced risk of atherosclerosis (Lee et al., 1994). In addition, animal models have demonstrated that CLA consumption inhibits the initiation of carcinogenesis and tumorigenesis, improves hyperinsulinemia, and enhances the immune system, as reviewed by Benjamin and Spener (2009).

One of the main factors affecting the milk FA profile, including CLA isomer content, is the diet (Nudda et al., 2006). Nutritional strategies, such as the addition soybean oil, have been used to produce CLA-enhanced milk (dos Santos et al., 2012).

The health of the animal throughout its life is another important factor that determines the nutritional quality of food derived from goats. Many changes associated with weaning expose a young goat to several stressors that can lead to depressed feed intake and growth performance and increase in disease and mortality (Pluske et al., 1996).

The application of probiotics in animal nutrition aims to promote production performance and prevent diseases via the maintenance of a healthy gastrointes- 
tinal environment and improvement of intestinal function (Chaucheyras-Durand et al., 2008; Mountzouris et al., 2009). Evidence has shown that the administration of Bifidobacterium licheniformis and Bifidobacterium subtilis in ewes had a beneficial effect on milk yields as well as milk fat and protein content (Kritas et al., 2006).

In a previous paper, the researchers of the current study found that the feeding of a mixture of potentially probiotic bacteria (MPPB) was able to modify gastrointestinal tract microbiota balance by reducing enterobacteria and increasing lactic acid bacteria and bifidobacteria, with a significant increase in animal weight (Apás et al., 2010). Moreover, the MPPB consumption was correlated with 10 -fold diminution of fecal putrescine (cancer and bacterial disease marker) and a $60 \%$ decrease in concentration of total fecal mutagens, indicating the protective effect of the treatment (Apás et al., 2010). Additionally, the MPPB exhibits the ability to bind and detoxify potent mutagens (Apás et al., 2014). Also, several strains of Bifidobacterium and Lactobacillus have been identified as potential producers of CLA (Rodríguez-Alcala et al., 2011). Some of these microorganisms are able to perform isomerization and dehydration of some precursor FA for CLA production (Kishino et al., 2009). Strategies to increase the levels of dietary or milk CLA, such as dietary intervention of ruminants, have been investigated (Stanton et al., 1997; Lawless et al., 1998).

The aims of this study were to evaluate the modification of intestinal content of FA profile and the intestinal morphology of weaned goats due to probiotic administration. In addition, we determined the effect of MPPB administration on the milk fat profile of lactating goats.

\section{MATERIALS AND METHODS}

\section{Bacterial Strains and Culture Conditions}

To create the probiotic mixture used in the current study, we used the following bacterial strains that had been isolated from feces collected from healthy goats, as previously reported (Draksler et al., 2004): Lactobacillus reuteri DDL 19, Lactobacillus alimentarius DDL 48, Enterococcus faecium DDE 39, and Bifidobacterium bifidum DDBA. To indicate their beneficial effects against goat fecal mutagens, the effect of these probiotics was previously investigated (Apás et al., 2010). In this study, each strain was cultured in an appropriate broth for $9 \mathrm{~h}$ at $37^{\circ} \mathrm{C}$. Lactobacillus reuteri DDL 19, L. alimentarius DDL 48, and E. faecium DDE 39 strains were cultured in de Man, Rogosa, and Sharpe (MRS) medium (Laboratorios Britania,
Buenos Aires, Argentina) at $\mathrm{pH}$ 5.5. Bifidobacterium bifidum DDBA was cultured in the same medium with the addition of $1 \%$ lactose at $\mathrm{pH} 7.0$, incubated at $37^{\circ} \mathrm{C}$ for $24 \mathrm{~h}$ in an anaerobic incubator (air-jacketed DH auto-flow $\mathrm{CO}_{2}$ incubator; NuAire Inc., Plymouth, MN) under microaerophilic conditions. Stock cultures were preserved in $10 \%$ skim milk at $4^{\circ} \mathrm{C}$. The MPPB was composed of $L$. reuteri DDL $19, L$. alimentarius DDL 48, E. faecium DDE 39, and B. bifidum DDBA in a $1: 1: 1: 1$ proportion at a final total concentration of $10^{9} \mathrm{cfu} / \mathrm{mL}$ resuspended in milk. To eliminate the native microbiota before inoculation, pasteurized milk was heated in the autoclave at $76 \mathrm{kPa}$ (0.75 atmospheres) for 5 min (Alberto et al., 2013). When the milk reached room temperature, the probiotic bacteria were added. For analysis of CLA production, the cells were resuspended in sterile distilled water at a final concentration of $10^{9} \mathrm{cfu} / \mathrm{mL}$.

\section{Weaning Goats}

The work was carried out with 2 batches of 10 animals each (Saanen-Creole), at the Instituto Nacional de Tecnología Agropecuaria (INTA) in Catamarca, Argentina. All procedures involving the animals and their handling and treatment were approved by the Ethics Committee for Use of Animals.

Immediately after weaning, 75-d-old goats selected by BW $(9.50 \pm 0.33 \mathrm{~kg})$ were used to evaluate the probiotic effect on the intestinal content of FA and intestinal morphology for $55 \mathrm{~d}$. Diet (g of dietary ingredients/ group per day) consisted of alfalfa: 1,200 (Medicago sativa; Prochin, La Pampa, Argentina); crushed maize grain: 800 (Zea mays; La Tijereta, Córdoba, Argentina); NaCl: 6.0; complex vitamins and minerals (Goat Power or Fast Forward; ADM Alliance Nutrition, Woodstock, ON, Canada), containing (per $\mathrm{kg}$ of DM) $450 \mathrm{mg}$ of nicotinic acid, $600 \mathrm{mg}$ of Mn, $950 \mathrm{mg}$ of $\mathrm{Zn}, 430 \mathrm{mg}$ of $\mathrm{Fe}, 650 \mathrm{mg}$ of $\mathrm{Cu}, 30 \mathrm{mg}$ of Se, $45 \mathrm{mg}$ of I, $20 \mathrm{mg}$ of $\mathrm{Co}$, $800 \mathrm{mg}$ of vitamin E, 45,000 IU of vitamin D, 120,000 IU of vitamin A; and protein and meat meal: 5.0 (Willmor S.A., Los Cardales, Buenos Aires, Argentina). Drinking water was given ad libitum. Five milliliters of MPPB was orally administered daily during treatment via syringe. The protocol included a 10-d probiotic supplementation into the milk (treated group) or the same milk without probiotic supplementation (control group) and then $5 \mathrm{~d}$ without milk administration in both groups. This protocol of probiotic administration was repeated 4 times. At the end of this cycle, the animals of each dietary treatment were weighed and then slaughtered at 10 to $11 \mathrm{~kg}$ of BW and 3 intestinal samples from each animal were obtained for histological and intestinal content studies. 


\section{Intestinal Content Analysis}

All the intestinal contents were collected and homogenized. Samples of $5 \mathrm{~mL}$ (weight $15 \pm 2 \mathrm{~g}$ ) were used to determine the composition of FA.

\section{FA Determination}

Lipids were extracted and analyzed by gas chromatography (Van Nieuwenhove et al., 2007). A gas chromatograph (model 6890N; Agilent Technologies Inc., Wilmington, DE) equipped with a flame ionization detector and an automatic injector (model 7683; Agilent Technologies Co. Ltd., Shanghai, China) was used. One microliter of derivatized sample was injected into an HP-88 capillary column $(100 \mathrm{~m} \times 0.32 \mathrm{~mm}$ i.d. $\times 0.25-\mu \mathrm{m}$ thick; Agilent Technologies Inc.). Gas chromatography conditions were as follows: injector temperature of $255^{\circ} \mathrm{C}$ and an initial oven temperature of $75^{\circ} \mathrm{C}$, which was increased to $165^{\circ} \mathrm{C}$ at $8^{\circ} \mathrm{C} / \mathrm{min}$ (held for $35 \mathrm{~min}$ ), then increased to $210^{\circ} \mathrm{C}$ at $5.5^{\circ} \mathrm{C} / \mathrm{min}$ (held for $2 \mathrm{~min}$ ), and finally, increased to $240^{\circ} \mathrm{C}$ at $15^{\circ} \mathrm{C} / \mathrm{min}$ (held for $3 \mathrm{~min}$ ). The temperature of the detector was $280^{\circ} \mathrm{C}$. Nitrogen was used as the carrier gas $(18 \mathrm{~mL} /$ min) with a pressure of 38 psi. Fatty acids were identified by comparing the retention times of methylated standards (99\%; Sigma, St. Louis, MO). Results were expressed as milligrams per gram of FA.

\section{Histological analysis}

The intestine was removed aseptically and the intestinal contents were placed in sterile flasks. The intestine was washed with physiological solution $(0.9 \%$ $\mathrm{NaCl}$ ) using a syringe. The intestinal content was kept at $4^{\circ} \mathrm{C}$ until processing. Small (jejunum) and large intestinal tissues were then taken from 3 goats of each experimental group for histological studies. Samples were immediately fixed with $10 \%$ neutral-buffered formalin, dehydrated in an alcohol-xylene series, and embedded in paraffin wax. Embedded tissues were then molded onto blocks for sectioning. Thin sections of $5-\mu \mathrm{m}$ thickness were cut on a microtome (Shandon Lipshaw Inc., Pittsburgh, PA), mounted on slides, and stained with hematoxylin and eosin (Fluka Chemical Corp., New York, NY). These sections were observed, photographed, and analyzed under a light microscope (Olympus BX 61; Olympus digital camera C-DP71, 12.1 megapixels; Olympus America Latina, Buenos Aires, Argentina).

\section{Lactating Goats}

The work was carried out with 2 batches of 6 randomized adult lactating goats in each batch (Saanen-
Creole) in Catamarca, Argentina. Only one batch received MPPB to evaluate this effect on FA content in the composition of milk fat.

The udders of goats were cleaned and the total milk collected from the milking was mixed and collected in sterile vials and placed at $4^{\circ} \mathrm{C}$ on the first day of the experiment (1 d after kidding), after $25 \mathrm{~d}$, and finally at the end of the treatment $(55 \mathrm{~d})$. The milk samples were stored in a freezer at $-20^{\circ} \mathrm{C}$ until processing.

The management protocol was similar to that described for weanling goats, only probiotic intake was 10 $\mathrm{mL} / \mathrm{d}$ per goat, instead of $5 \mathrm{~mL}$. Regarding fed goats, this was managed under a semi-extensive system, based on forage production of species adapted to subtropical conditions (Panicum and Cenchrus spp.). The following supplements were administered ( $\mathrm{g}$ of dietary ingredients/goat per day): alfalfa hay: 400; maize grain: 300; NaCl: 6.0; complex vitamins and minerals (ADM Alliance Nutrition Goat Power or Fast Forward, Canada), containing (per kg of DM) $450 \mathrm{mg}$ of nicotinic acid, 600 $\mathrm{mg}$ of $\mathrm{Mn}, 950 \mathrm{mg}$ of $\mathrm{Zn}, 430 \mathrm{mg}$ of $\mathrm{Fe}, 650 \mathrm{mg}$ of $\mathrm{Cu}$, $30 \mathrm{mg}$ of Se, $45 \mathrm{mg}$ of I, $20 \mathrm{mg}$ of Co, $800 \mathrm{mg}$ of vitamin E, 45,000 IU of vitamin D, and 120,000 IU of vitamin A; and proteins and meat meal: 7.0. Drinking water was given ad libitum. All procedures involving the animals and their handling and treatment were approved by the Ethics Committee for Use of Animals at the Instituto Nacional de Tecnología Agropecuaria (INTA).

\section{Milk FA Analysis}

Aliquots of $5 \mathrm{~mL}$ of milk (approximately $10 \mathrm{~g}$ ) were taken from 6 adult goats for control and 6 adult goats for treatment. Lipids were extracted and analyzed as previously described.

The atherogenicity index was calculated using the following equation (Chilliard et al., 2003):

$$
\text { atherogenicity index }=\frac{\mathrm{C} 12: 0+4 \times \mathrm{C} 14: 0+\mathrm{C} 16: 0}{\text { MUFA }+ \text { PUFA }} .[1]
$$

The atherogenicity index represents the relationship between hypercholesterolemic and protective FA (Ulbricht and Southgate, 1991). Lower index values indicate a healthier fat composition.

\section{In Vitro Bacterial CLA Production}

Lactobacillus reuteri DDL 19, L. alimentarius DDL 48, E. faecium DDE 39, and B. bifidum DDBA, and the mixed culture $[1 \%(\mathrm{vol} / \mathrm{vol})$ each $]$ were inoculated in MRS broth containing $200 \mu \mathrm{g} / \mathrm{mL}$ linoleic acid $(99 \%$ pure; Sigma) as substrate. Linoleic acid was dissolved in $1 \%$ (vol/vol) Tween 80 (polyoxyethylene sorbitan 
monooleate; Merck KGaA, Darmstadt, Germany) to improve its solubility. Cultures were anaerobically incubated at $37^{\circ} \mathrm{C}$ for $24 \mathrm{~h}$ in an anaerobic incubator (air-jacketed DH auto-flow $\mathrm{CO}_{2}$ incubator, NuAire Inc.) under microaerophilic conditions.

Lipids were extracted from probiotic cultures and noninoculated sterile media (control) using chloroform/ methanol $(2: 1, \mathrm{vol} / \mathrm{vol})$ solution (Folch et al., 1957), and then they were saponified with $4 \mathrm{~mL}$ of methanolic $\mathrm{NaOH}\left(0.9 \%\right.$, wt/vol) at $100^{\circ} \mathrm{C}$ for $30 \mathrm{~min}$. Free FA were extracted twice with hexane $(6$ and $3 \mathrm{~mL}$, respectively), to collect the upper organic phase. Recovered FA were derivatized to methyl esters (FAME) (Chin et al., 1994). Fatty acid methyl esters were dissolved in hexane $(1 \mathrm{~mL})$ and kept at $-20^{\circ} \mathrm{C}$ until gas chromatography analysis.

\section{Statistical Analysis}

Data were represented as mean \pm standard deviation and were submitted to one-way ANOVA using InfoStat statistical software (2011; National University of Córdoba, Córdoba, Argentina); $P$-values of $<0.05$ were considered statistically significant.

\section{RESULTS AND DISCUSSION}

\section{Composition of Intestinal FA Content}

The composition of FA in the goat intestine is presented in Table 1. Among SFA, only the concentration of stearic acid (18:0) was $5.5 \mathrm{~g} / 100 \mathrm{~g}$ (45\%) higher $(P<0.05)$ in the probiotic group. It is well known that stearic acid does not generate any harm to human health and that oleic acid acts as a protective atherogenic (Gagliostro, 2004).With respect to MUFA, probiotic consumption increased the concentrations of palmitoleic acid and oleic acid by 0.85 and $1.06 \mathrm{~g} / 100$ $\mathrm{g}$ of FA, respectively. Regarding PUFA, the probiotic improved the concentration of significantly more PUFA compared with the control. The amounts of linoleic (C18:2n-6), CLA (cis-9,trans-11 C18:2), and docosahexaenoic acid (C22:06) increased 23\% (from 8.85 to $10.85 \mathrm{~g} / 100 \mathrm{~g}$ of $\mathrm{FA}$ ), $344 \%$ (from 0.18 to $0.80 \mathrm{~g} / 100$ $\mathrm{g}$ of FA), and $74 \%$ (from 0.95 to $1.65 \mathrm{~g} / 100 \mathrm{~g}$ of FA), respectively, with respect to the control group. Polyunsaturated FA exert many health-promoting effects, including anticarcinogenic, antimutagenic, hypocholesterolemic, and antiatherosclerotic effects (Jensen, 2002). Our results may be partially elucidated by our previous work where we demonstrated that consumption of the probiotic mixture by goats reduces gram-negative bacterial development, intestinal mutagenicity, and putrescine levels (Apás et al., 2010). Our results provide the first evidence of an improvement in the profile of intestinal FA content after probiotic mixture $\left(10^{9} \mathrm{cfu} /\right.$ $\mathrm{mL}$ ) administration to weaned goats.

\section{Intestinal Morphology}

Comparative studies between small intestinal tissue of animals with and without probiotic consumption are shown in Figure 1. Samples from the treatment group showed higher integrity of the intestinal villi, lower cellular infiltration, and inhibition of epithelial inflammation (Figure 1B and D) with respect to the control group (Figure 1A and $\mathrm{C}$ ). These results are similar to those reported in probiotic-fed chickens (Pelicano et al., 2003) and in mice (Frizzo et al., 2005). The integrity of epithelia is critical, as toxins and microorganisms that are able to breach the single layer of epithelial cells have unimpeded access to the systemic circulation (Schierack et al., 2006).

Comparative studies between large intestinal tissue of animals with and without probiotic consumption are shown in Figure 2. Eimeria spp. oocysts were observed in control samples (Figure 2A) but not in tissues from the treatment group (Figure 2B). The genus Eimeria is

Table 1. Quantity of FA in the intestinal content of goats ${ }^{1}$

\begin{tabular}{lcc}
\hline FA $^{2}$ & Control group & Treatment group \\
\hline 12:0 (lauric acid) & $0.95 \pm 0.07^{\mathrm{a}}$ & $0.85 \pm 0.07^{\mathrm{a}}$ \\
14:0 (myristic acid) & $1.95 \pm 0.07^{\mathrm{a}}$ & $1.85 \pm 0.07^{\mathrm{a}}$ \\
16:0 (palmitic acid) & $21.15 \pm 1.34^{\mathrm{a}}$ & $20.70 \pm 0.99^{\mathrm{a}}$ \\
18:0 (stearic acid) & $11.55 \pm 0.35^{\mathrm{a}}$ & $16.80 \pm 0.57^{\mathrm{b}}$ \\
16:01 (palmitoleic acid) & $1.05 \pm 0.08^{\mathrm{a}}$ & $1.90 \pm 0.14^{\mathrm{b}}$ \\
18:1 (oleic acid) & $15.30 \pm 0.32^{\mathrm{a}}$ & $16.36 \pm 0.40^{\mathrm{b}}$ \\
18:2 (linoleic acid) & $8.85 \pm 0.64^{\mathrm{a}}$ & $10.85 \pm 0.21^{\mathrm{b}}$ \\
cis-9, trans-11 18:2 (CLA) & $0.18 \pm 0.04^{\mathrm{a}}$ & $0.80 \pm 0.14^{\mathrm{b}}$ \\
20:05 (EPA) & $0.80 \pm 0.14^{\mathrm{a}}$ & $0.95 \pm 0.21^{\mathrm{a}}$ \\
22:06 (DHA) & $0.95 \pm 0.07^{\mathrm{a}}$ & $1.65 \pm 0.21^{\mathrm{b}}$ \\
${ }^{\mathrm{a}, \mathrm{b}}$ Different superscript letters for each FA (within a row) indicate significant differences $(P<0.034)$. \\
${ }^{1}$ Results are mean \pm SD of FA (g/100 g).
\end{tabular}




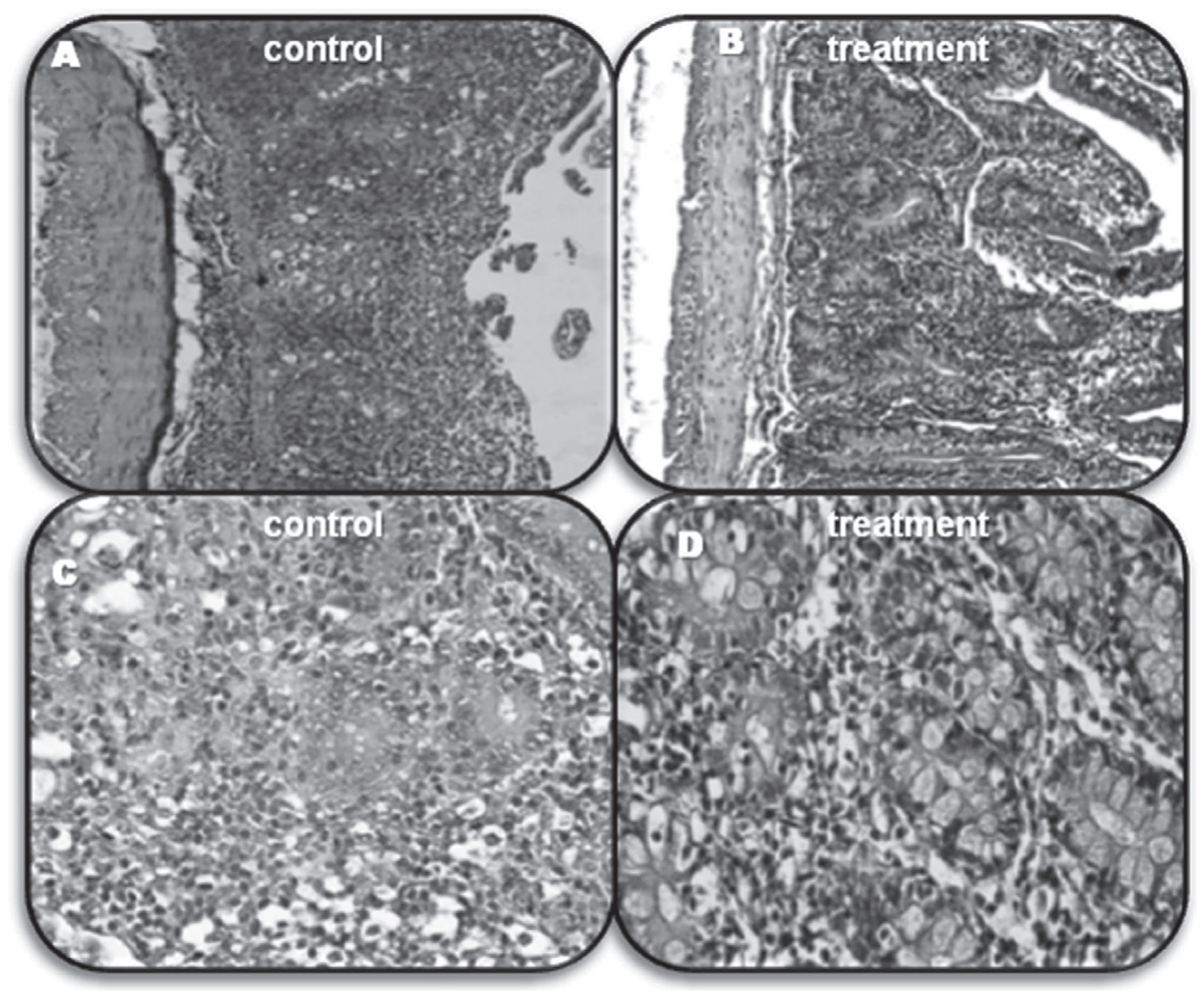

Figure 1. Probiotic administration effect on the goat small intestine. Histological analysis of the small intestine: A and C: control; B and D: mixture of potentially probiotic bacteria (MPPB)-supplemented group; $10 \times$ hematoxylin/eosin staining was used.

one of the main parasites found in goats (Palacios et al., $2004)$ that cause coccidiosis. These results are in agreement with previous studies that indicate a decrease in parasitic infection after probiotic supplementation in animals (Draksler et al., 2004; Ross et al., 2010). In addition, the results also indicate that samples from probiotic-treated animals reflect a preserved glandular structure (Figure 2B).

It is well known that metabolic products of lactic bacteria (lactic acid, acetic acid, and butyric acid) play an important role in the renewal of the intestinal epithelium and serve as an energy source (Williams and Jackson, 2002). It was, therefore, speculated that the structural conservation seen in the intestinal morphology could be associated with probiotic treatment. The results obtained in the present study indicate that probiotic mixture administration had a beneficial effect on intestinal morphology.

\section{FA Composition of Goat Milk Samples}

Milk FA composition of the goats is presented in Table 2. The mean FA concentration ( $\mathrm{g}$ of FA/100 $\mathrm{g}$ of goat milk) for the treatment and control groups were 3.87 and $3.21 \%$, respectively.

The concentrations of lauric and palmitic acids after $55 \mathrm{~d}$ of kidding were decreased due to probiotic feeding, from 2.235 to $1.690 \mathrm{~g}$ of FA/L of milk, and from 5.261 to $4.402 \mathrm{~g}$ of FA/L of milk, respectively. Palmitic and oleic acids were predominant in milk control and treatment groups, in concordance with levels previously reported (Luna et al., 2005). In contrast, MPPB ingestion increased the CLA content by almost 2-fold with respect to the control value (from 0.0093 to $0.232 \mathrm{~g}$ of FA/L of milk). The MPPB treatment given to the goats modified the lipid profile of the milk, with a significant increase in the CLA content. In addition, the concentration of oleic, linoleic, and linolenic acids increased from 4.290 to $7.585 \mathrm{~g}$ of $\mathrm{FA} / \mathrm{L}$ of milk, from 0.701 to $1.393 \mathrm{~g}$ of FA/L of milk, and from 0.063 to $0.187 \mathrm{~g}$ of FA/L of milk, respectively, due to MPPB administration. These functional PUFA, although present in small concentrations in milk fat, exert many health-promoting effects, including anticarcinogenic, antimutagenic, hypocholesterolemic, and antiatherosclerotic effects (Jahries et al., 1999; Jensen, 2002). Our results could explain the fact 


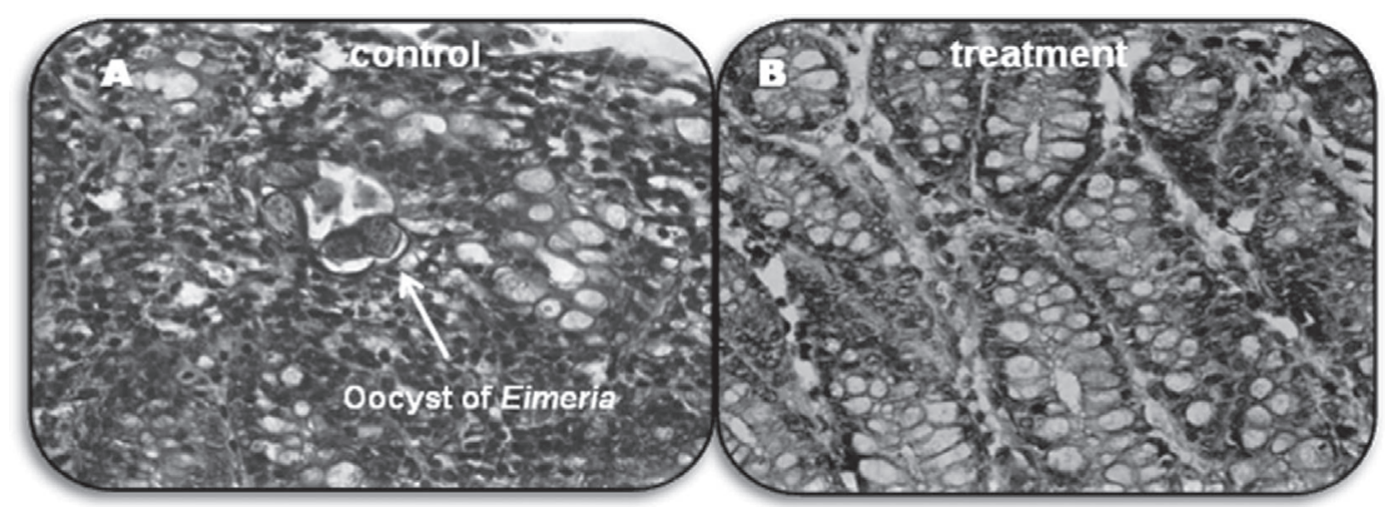

Figure 2. Probiotic administration effect on the goat large intestine. Histological analysis of the large intestine of goats: A: control group; B: mixture of potentially probiotic bacteria (MPPB)-supplemented group; $60 \times$ hematoxylin/eosin staining was used.

that changes seen in the milk FA composition could be associated with lactic acid bacteria consumption (Maragkoudakis et al., 2010).

\section{Atherogenicity Index}

After the 55-d trial, milk atherogenicity index values of the treatment group $(P<0.05)$ were lower than those of the controls. The atherogenicity index value observed in treatment and control groups were 1.77 and 3.32 , respectively, after the 55-d trial. Our results are similar to the atherogenicity index values ascertained by a previous study of goat milk and dairy products (Bobe et al., 2004). The atherogenicity index is linked to the possibility of blocked arteries. A high atherogenicity index promotes adhesion to cells of the immune and circulatory systems. Conversely, a low atherogenicity index prevents the occurrence of micro- and macrocoronary disease (Ulbricht and Southgate, 1991).

\section{Bacterial CLA Production}

Lactobacillus reuteri DDL 19, L. alimentarius DDL 48, E. faecium DDE 39, B. bifidum DDBA, and the

Table 2. Variation in milk FA profile in lactating goats with (treatment group) and without (control group) mixture of potentially probiotic bacteria (MPPB) consumption ${ }^{1}$

\begin{tabular}{lccc}
\hline FA & Time (d) & Control group & Treatment group \\
\hline 12:0 (lauric acid) & 0 & $1.027 \pm 0.272^{\mathrm{a}}$ & $1.399 \pm 0.281^{\mathrm{a}}$ \\
& 25 & $1.667 \pm 0.067^{\mathrm{a}}$ & $1.858 \pm 0.103^{\mathrm{a}}$ \\
14:0 (myristic acid) & 55 & $2.235 \pm 0.156^{\mathrm{a}}$ & $1.690 \pm 0.310^{\mathrm{b}}$ \\
& 0 & $1.790 \pm 0.201^{\mathrm{a}}$ & $2.125 \pm 0.082^{\mathrm{a}}$ \\
& 25 & $2.920 \pm 0.036^{\mathrm{a}}$ & $3.096 \pm 0.077^{\mathrm{b}}$ \\
16:0 (palmitic acid) & 55 & $2.450 \pm 0.257^{\mathrm{a}}$ & $2.498 \pm 0.235^{\mathrm{a}}$ \\
& 0 & $3.896 \pm 0.255^{\mathrm{a}}$ & $4.104 \pm 0.084^{\mathrm{a}}$ \\
& 25 & $4.748 \pm 0.211^{\mathrm{a}}$ & $4.109 \pm 0.345^{\mathrm{b}}$ \\
18:0 (stearic acid) & 55 & $5.261 \pm 0.361^{\mathrm{a}}$ & $4.402 \pm 0.447^{\mathrm{b}}$ \\
& 0 & $2.121 \pm 0.270^{\mathrm{a}}$ & $2.357 \pm 0.097^{\mathrm{a}}$ \\
& 25 & $2.146 \pm 0.032^{\mathrm{a}}$ & $2.905 \pm 0.043^{\mathrm{b}}$ \\
18:1 (oleic acid) & 55 & $2.525 \pm 0.164^{\mathrm{a}}$ & $3.120 \pm 0.298^{\mathrm{b}}$ \\
& 0 & $3.831 \pm 0.499^{\mathrm{a}}$ & $4.054 \pm 0.684^{\mathrm{a}}$ \\
18:2 (linoleic acid) & 25 & $3.081 \pm 0.117^{\mathrm{a}}$ & $4.331 \pm 0.104^{\mathrm{b}}$ \\
& 55 & $4.290 \pm 0.324^{\mathrm{a}}$ & $7.585 \pm 0.205^{\mathrm{b}}$ \\
18:3 (linolenic acid) & 0 & $0.210 \pm 0.021^{\mathrm{a}}$ & $0.229 \pm 0.205^{\mathrm{a}}$ \\
& 25 & $0.303 \pm 0.033^{\mathrm{a}}$ & $0.413 \pm 0.027^{\mathrm{b}}$ \\
cis-9, trans-11 18:2 (CLA) & 55 & $0.701 \pm 0.123^{\mathrm{a}}$ & $1.393 \pm 0.059^{\mathrm{b}}$ \\
& 0 & $0.075 \pm 0.013^{\mathrm{a}}$ & $0.106 \pm 0.039^{\mathrm{a}}$ \\
& 25 & $0.104 \pm 0.022^{\mathrm{a}}$ & $0.191 \pm 0.040^{\mathrm{b}}$ \\
& 55 & $0.063 \pm 0.027^{\mathrm{a}}$ & $0.187 \pm 0.024^{\mathrm{b}}$ \\
& 0 & $0.049 \pm 0.006^{\mathrm{a}}$ & $0.058 \pm 0.034^{\mathrm{b}}$ \\
& 25 & $0.033 \pm 0.014^{\mathrm{a}}$ & $0.049 \pm 0.010^{\mathrm{a}}$ \\
& 55 & $0.093 \pm 0.004^{\mathrm{a}}$ & $0.232 \pm 0.007^{\mathrm{b}}$
\end{tabular}

${ }^{\mathrm{a}-\mathrm{b}}$ Different superscript letters for each FA and for each time (within a row) indicate significant differences $(P$ $<0.041)$.

${ }^{1}$ Results are mean $\pm \mathrm{SD}$ of FA (g of FA/L of milk) 
mixed culture $[1 \%$ (vol/vol) each $]$ were not able to conjugate linoleic acid to CLA. These results are in agreement with the negative effect to conjugate linoleic acid to CLA observed in some lactic acid bacteria (Jiang et al., 1999). In contrast with our results, evidence of CLA production is well known in Bifidobacteria and Lactobacillus spp. (Coakley et al., 2003; Rodríguez-Alcala et al., 2011) and for Butyrivibrio fibrisolvens present in the rumen (Kepler et al., 1966; Wallace et al., 2007). Moreover, the probiotic mixture of Lactobacillus acidophilus, Lactobacillus delbrueckii ssp. bulgaricus, Lactobacillus casei, Lactobacillus plantarum, Bifidobacterium breve, Bifidobacterium infantis, Bifidobacterium longum, and Streptococcus thermophilus, were all able to produce CLA in vitro. Furthermore, when this probiotic mixture was fed to mice, it exhibited a 100-fold increase in the capacity of the fecal content for the formation of CLA under anaerobic conditions (Ewaschuk et al., 2006).

Ruminant-derived meat and dairy products have traditionally been a primary source of dietary CLA intake for humans (Jiang et al., 1999). Antiinflammatory and anticancer properties are among the wide array of health-promoting effects associated with isomers of CLA (Cook et al., 1993; Ha et al., 1987). The biological effects of CLA have been attributed to a decrease in the synthesis of arachidonic acid-derived eicosanoids, such as prostaglandins and leukotrienes, involved in inflammation, and to the modulation of gene expression involved in lipid metabolism, apoptosis, and immune function (Belury, 2002).

\section{CONCLUSIONS}

The results obtained in present study indicate that a probiotic mixture administration in weaned goats had beneficial effects on the intestinal morphology, as dramatic disturbances occurred during critical phases, such as the weaning period, and an enhanced MUFA and PUFA concentration in the intestinal content was observed. The probiotic consumption by lactating goats modified the FA profiles of the milk, with an increased in the concentration of several PUFA and the diminution of the atherogenic index.

\section{ACKNOWLEDGMENTS}

The authors thank Consejo de Investigación de la Universidad Nacional de Tucumán (CIUNT; Tucumán, Argentina; 26-D-429), Consejo Nacional de Investigaciones Científicas y Técnicas (CONICET; Buenos Aires, Argentina; PIP 0343), and Agrovalor Project and Agencia Nacional de Promoción Científica y Tecnológica (ANCyT; Buenos Aires, Argentina; PICT 816/06 and PICT $2011 \mathrm{~N}^{\circ} 2012$ ) for their grants.

\section{REFERENCES}

Alberto, M. R., M. F. Perera, and M. E. Arena. 2013. Lactic acid fermentation of peppers. Food Nutr. Sci. 4:47-55.

Apás, A. L., J. Dupraz, R. Ross, S. N. González, and M. E. Arena. 2010. Probiotic administration effect on fecal mutagenicity and microflora in the goat's gut. J. Biosci. Bioeng. 110:537-540.

Apás, A. L., S. N. González, and M. E. Arena. 2014. Potential of goat probiotic to bind mutagens. Anaerobe 28:8-12.

Belury, M. A. 2002. Dietary conjugated linoleic acid in health: Physiological effects and mechanisms of action. Annu. Rev. Nutr. 22:505-531.

Benjamin, S., and S. Spener. 2009. Conjugated linoleic acids as functional food: An insight into their health benefits. Nutr. Metab. $6: 36$.

Bobe, G., S. Zimmerman, E. Hammond, G. Freeman, G. Lindberg, and D. Beitz. 2004. Texture of butters made from milks differing in indices of atherogenicity. Iowa State University Animal Industry Report, A. S. Leaflet R1902. Iowa State University, Ames.

Chaucheyras-Durand, F., N. D. Walker, and A. Bach. 2008. Effects of active dry yeasts on the rumen microbial ecosystem: Past, present and future. Anim. Feed Sci. Technol. 145:5-26.

Chilliard, Y., A. Ferlay, J. Rouel, and G. Lamberet. 2003. A review of nutritional and physiological factors affecting goat milk lipid synthesis and lipolysis. J. Dairy Sci. 86:1751-1770.

Chin, S. F., J. M. Storkson, W. Liu, K. J. Albright, and M. W. Pariza. 1994. Conjugated linoleic acid (9,11- and 10,12-octadecadienoic acid) is produced in conventional but not germ-free rats fed linoleic acid. J. Nutr. 124:694-701.

Coakley, M., R. Ross, M. Nordgren, G. Fitzgerald, R. Devery, and C. Stanton. 2003. Conjugated linoleic acid biosynthesis by humanderived Bifidobacterium species. J. Appl. Microbiol. 94:138-145.

Cook, M. E., C. C. Miller, Y. Park, and M. Pariza. 1993. Immune modulation by altered nutrient metabolism: nutritional control of immune-induced growth depression. Poult. Sci. 72:1301-1305.

DeLany, J. P., F. Blohm, A. Truett, J. A. Scimeca, and D. B. West. 1999. Conjugated linoleic acid rapidly reduces body fat content in mice without affecting energy intake. Am. J. Physiol. 276:R1172R1179.

dos Santos, K. M. O., M. A. D. Bomfim, A. D. S. Vieira, S. D. Benevides, S. M. I. Saad, F. C. A. Buriti, and A. S. Egito. 2012. Probiotic caprine Coalho cheese naturally enriched in conjugated linoleic acid as a vehicle for Lactobacillus acidophilus and beneficial fatty acids. Int. Dairy J. 24:107-112.

Draksler, D., M. C. Monferrán, and S. González. 2004. Interactions between acid lactic bacteria and gastrointestinal nematodes of caprine origin. Pages 207-212 in Public Health Microbiology. J. F. T. Spencer and A. L. Ragout de Spencer, ed. Humana Press, Totowa, NJ

Ewaschuk, J. B., J. W. Walker, H. Diaz, and K. L. Madsen. 2006. Bioproduction of conjugated linoleic acid by probiotic bacteria occurs in vitro and in vivo in mice. J. Nutr. 136:1483-1487.

Folch, J., M. Lees, and G. Sloane Stanley. 1957. A simple method for the isolation and purification of total lipids from animal tissues. J. Biol. Chem. 226:497-509.

Frizzo, L. S., C. Peralta, V. Zbrun, E. Bertozzi, L. P. Soto, E. Marti, R. Dalla Santina, G. J. Sequeira, and M. R. Rosmini. 2005. Respuesta de ratones inoculados con bacterias lácticas de origen bovino a un desafío con Salmonella Dublin. Rev. FAVE - Cien. Vet. (Kiev) 4:41-53.

Gagliostro, G. A. 2004. Control Nutricional del contenido de ácido linoleico conjugado (CLA) en leche y su presencia en alimentos naturales funcionales. 1. Efectos sobre la salud humana. Rev. Arg. Prod. Anim. 24:113-136.

Ha, Y. L.. N. K. Grimm, and M. W. Pariza. 1987. Anticarcinogens from fried ground beef: Heat-altered derivatives of linoleic acid. Carcinogenesis 8:1881-1887.

Ha, Y. L., J. Storkson, and M. W. Pariza. 1990. Inhibition of benzo(a) pyrene-induced mouse forestomach neoplasia by conjugated dienoic derivatives of linoleic acid. Cancer Res. 50:1097-1101. 
Ip, C., S. F. Chin, J. A. Scimeca, and M. W. Pariza. 1991. Mammary cancer prevention by conjugated dienoic derivative of linoleic acid. Cancer Res. 51:6118-6124.

Jahries, G., J. Fritsche, P. Möckel, F. Schöne, U. Möller, and H. Steinhart. 1999. The potential anticarcinogenic conjugated linoleic acid, cis-9,trans-11 C18:2, in milk of different species: Cow, goat, ewe, sow, mare, woman. Nutr. Res. 19:1541-1549.

Jensen, R. G. 2002. The composition of bovine milk lipids. J. Dairy Sci. 85:295-350.

Jiang, J., A. Wolk, and B. Vessby. 1999. Relation between the intake of milk fat and the occurrence of conjugated linoleic acid in human adipose tissue. Am. J. Clin. Nutr. 70:21-27.

Jones, E. L., K. J. Shingfield, C. Kohen, A. K. Jones, B. Lupoli, A. S. Grandison, D. E. Beever, C. M. Williams, P. C. Calder, and P. Yaqoob. 2005. Chemical, physical, and sensory properties of dairy products enriched with conjugated linoleic acid. J. Dairy Sci. 88:2923-2937.

Kepler, C. R., K. P. Hirons, J. J. McNeill, and S. B. Tove. 1966. Intermediates and products of the biohydrogenation of linoleic acid by Butyrivibrio fibrisolvens. J. Biol. Chem. 241:1350-1354.

Kishino, S., J. Ogawa, K. Yokozeki, and S. Shimizu. 2009. Microbial production of conjugated fatty acids. Lipid Technol. 21:177-181.

Kritas, S. K., A. Govaris, G. Christodoulopoulos, and A. R. Burriel. 2006. Effect of Bacillus licheniformis and Bacillus subtilis supplementation of ewe's feed on sheep milk production and young lamb mortality. J. Vet. Med. A Physiol. Pathol. Clin. Med. 53:170-173.

Lawless, F., J. J. Murphy, D. Harrington, R. Devery, and C. Stanton. 1998. Elevation of conjugated cis-9, trans-11 octadecadienoic acid in bovine milk because of dietary supplementation. J. Dairy Sci. 81:3259-3267.

Lee, K. N., D. Kritchevsky, and M. W. Pariza. 1994. Conjugated linoleic acid and atherosclerosis in rabbits. Atherosclerosis 108:19-25.

Luna, P., M. Juárez, and M. De La Fuente. 2005. Validation of a rapid milk fat separation method to determine the fatty acid profile by gas chromatography. J. Dairy Sci. 88:3377-3381.

Maragkoudakis, P. A., K. C. Mountzouris, C. Rosu, G. Zoumpopoulou, K. Papadimitriou, E. Dalaka, A. Hadjipetrou, G. Theofanous, G. P. Strozzi, N. Carlini, G. Zervas, and E. Tsakalidou. 2010. Feed supplementation of Lactobacillus plantarum PCA 236 modulates gut microbiota and milk fatty acid composition in dairy goats- $\mathrm{A}$ preliminary study. Int. J. Food Microbiol. 141:S109-S116.

Mountzouris, K. C., C. Balaskas, I. Xanthakos, A. Tzivinikou, and K. Fegeros. 2009. Effects of a multi-species probiotic on biomarkers of competitive exclusion efficacy in broilers challenged with Salmonella enteritidis. Br. Poult. Sci. 50:467-478.

Nudda, A., G. Battacone, M. G. Usai, S. Fancellu, and G. Pulina. 2006. Supplementation with extruded linseed cake affects concentrations of conjugated linoleic acid and vaccenic acid in goat milk. J. Dairy Sci. 89:277-282.

Palacios, C. E., L. N. Tabacchi, A. C. Chavera, T. U. López, G. A. Santillán, N. C. Sandoval, D. C. Pezo, and R. C. Perales. 2004. Eimeriosis en crías de alpacas: Estudio anátomo histopatológico. Rev. Investig. Vet. Perú 15:174-178.
Parodi, P. W. 1997. Cows' milk fat components as potential anticarcinogenic agents. J. Nutr. 127:1055-1060.

Pelicano, E. R. L., P. A. Souza, H. B. A. Souza, A. Oba, E. A. Norkus, L. M Kodawara, and T. M. A. Lima. 2003. Morfometría e ultraestrutura da mucosa intestinal de frangos de corte alimentados com dietas contendo diferentes probióticos. Rev. Port. Ciên. Vet. (Kiev) 98:125-134.

Piperova, L. S., U. Moallem, B. B. Teter, J. Sampugna, M. P. Yurawecz, K. M. Morehouse, D. Luchini, and R. A. Erdman. 2004. Changes in milk fat in response to dietary supplementation with calcium salts of trans-18:1 or conjugated linoleic fatty acids in lactating dairy cows. J. Dairy Sci. 87:3836-3844.

Pluske, J. R., I. H. Williams, and F. X. Aherne. 1996. Villus height and crypt depth in piglets in response to increased intake of cows milk after weaning. Anim. Sci. 62:145-158.

Rodríguez-Alcala, L. M., T. Braga, F. X. Malcata, A. Gomes, and J. Fontecha. 2011. Quantitative and qualitative determination of CLA produced by Bifidobacterium and LAB by combining spectrophotometric and $\mathrm{Ag}^{+}$-HPLC techniques. Food Chem. 125:1373-1378.

Ross, G. R. C. Gusils, R. Oliszewski, S. C. de Holgado, and S. N. González. 2010. Effects of probiotic administration in swine. J. Biosci. Bioeng. 109:545-549.

Schierack, P., M. Nordhoff, M. Pollmann, K. D. Weyrauch, S Amasheh, U. Lodemann, J. Jores, B. Tachu, S. Kleta, A. Blikslager, K. Tedin, and L. H. Wieler. 2006. Characterization of a porcine intestinal epithelial cell line for in vitro studies of microbial pathogenesis in swine. Histochem. Cell Biol. 125:293-305.

Serafeimidou, A., S. Zlatanos, K. Laskaridis, and A. Sagredos. 2012. Chemical characteristics, fatty acid composition and conjugated linoleic acid (CLA) content of traditional Greek yogurts. Food Chem. 134:1839-1846.

Stanton, C., F. Lawless, G. Kjellmer, D. Harrington, R. Devery, J. F. Connolly, and J. Murphy. 1997. Dietary influences on bovine milk cis-9,trans-11-conjugated linoleic acid content. J. Food Sci. 62:1083-1086.

Ulbricht, T. L., and D. A. Southgate. 1991. Coronary heart disease: Seven dietary factors. Lancet 338:985-992.

Van Nieuwenhove, C. P., R. Oliszewski, S. N. González, and A. B. Pérez Chaia. 2007. Conjugated linoleic acid conversion by dairy bacteria cultured in MRS broth and buffalo milk. Lett. Appl. Microbiol. 44:467-474.

Wallace, R. J., N. McKain, K. J. Shingfield, and E. Devillard. 2007. Isomers of conjugated linoleic acids are synthesized via different mechanisms in ruminal digest and bacteria. J. Lipid Res. 48:2247-2254.

West, D. B., J. P. Delany, P. M. Camet, F. Blohm, A. A. Truett, and J. Scimeca. 1998. Effects of conjugated linoleic acid on body fat and energy metabolism in the mouse. Am. J. Physiol. 275:R667R672.

Williams, C. M., and K. G. Jackson. 2002. Inulin and oligofructose: Effects on lipid metabolism from human studies. Br. J. Nutr. 87(Suppl. S2):S261-S264. 